\title{
Nutrition, Fiber
}

National Cancer Institute

\section{Source}

National Cancer Institute. Nutrition, Fiber. NCI Thesaurus. Code C15225.

Role of dietary fiber in cancer causation or prevention and in general health. 